\title{
Anthracnose and Gummy Stem Blight Are Reduced on Watermelon Grown on a No-Till Hairy Vetch Cover Crop
}

X. G. Zhou, Texas A\&M University System, AgriLife Research and Extension Center, Beaumont 77713; and K. L. Everts, University of Maryland, Lower Eastern Shore Research and Education Center, Salisbury 21801, and University of Delaware, Research and Education Center, Georgetown 19947

\begin{abstract}
Zhou, X. G., and Everts, K. L. 2012. Anthracnose and gummy stem blight are reduced on watermelon grown on a no-till hairy vetch cover crop. Plant Dis. 96:431-436.

Multiple applications of fungicides are used to manage anthracnose caused by Colletotrichum orbiculare and gummy stem blight caused by Didymella bryoniae, the two most common and destructive diseases on watermelon (Citrullus lanatus) in the mid-Atlantic region of the United States. To develop a sustainable, nonchemical management option, a split-plot experiment was conducted over 3 years to evaluate the effects of a no-till hairy vetch (Vicia villosa) cover crop on disease severity, plant growth, and fruit yield compared with two conventional bedding systems and fungicide application. The main plots were bedding strategies consisting of bare ground, polyethylene covering, or a hairy vetch cover crop that was planted in the fall, killed the following spring, and left on the soil surface as an organic mulch. The subplots were a nonfungicide control or a weekly application of a standard fungicide program. Hairy vetch mulch provided greater than a $65 \%$

and gummy stem blight and greater than an $88 \%$ decrease in diseased fruit compared with bare ground or polyethylene mulch. The reductions were comparable with those achieved by fungicide applications. Watermelon vine lengths in plots with hairy vetch were similar to or greater than those in plots with polyethylene or bare ground that were treated with fungicides. Marketable fruit in plots with hairy vetch was higher compared with bare ground in 2 of 3 years and was similar to that in plots treated with fungicides in all 3 years. Addition of fungicide application to hairy vetch treatment further reduced anthracnose in 1 year and gummy stem blight in 2 years but did not significantly increase fruit yield in all 3 years. This is the first demonstration that a no-till hairy vetch production system can reduce anthracnose and gummy stem blight on watermelon and that the production system has the potential to mitigate damage caused by these diseases.
\end{abstract} reduction in the area under the disease progress curves of anthracnose
Watermelon (Citrullus lanatus (Thunb.) Matsum. \& Nakai) is one of the most widely grown fresh vegetables in the mid-Atlantic region of the United States, where crops are primarily produced on irrigated land with black polyethylene mulch. Anthracnose, caused by Colletotrichum orbiculare (Berk.) Arx (syn. C. lagenarium (Pass.) Ellis \& Halst.), and gummy stem blight, caused by Didymella bryoniae (Fuckel) Rehm, are the two most common and destructive foliar diseases of watermelon in the region. Both diseases, each with distinguishable symptoms on infected parts of plants $(19,20)$, can cause severe damage to foliage, stem, and fruit, which may result in more than $40 \%$ yield losses under highly conducive environmental conditions (9). Currently, fungicides are the most effective and reliable method to manage these diseases. Watermelon growers rely heavily on fungicides and up to 10 applications per season may be used to limit yield losses due to anthracnose and gummy stem blight (28). More fungicides are applied during watermelon production than insecticides and herbicides, accounting for more than $65 \%$ of the total chemicals used annually on watermelon in the United States (4). Although management with fungicides is necessary to reduce disease and increase marketable fruit yield and quality (8), multiple fungicide applications significantly increase production costs and reduce profitability. Increased use of fungicides also increases the potential for the development of fungicide-resistant pathogens. Resistance in $D$.

Corresponding author: K. L. Everts, E-mail: keverts@umd.edu

Former address of X. G. Zhou: University of Maryland, Lower Eastern Shore Research and Education Center, Salisbury 21801.

Accepted for publication 23 October 2011.

http://dx.doi.org/10.1094/PDIS-07-11-0608

(C) 2012 The American Phytopathological Society bryoniae has been found to azoxystrobin, benomyl, and thiophanate-methyl $(6,11,21)$.

Introduction of a cover crop into current watermelon production systems may reduce disease severity and provide a means to mitigate problems associated with fungicide use. Recent research has demonstrated a reduction of disease on watermelon following a legume hairy vetch (Vicia villosa Roth) cover crop $(10,25,28,29)$. Inclusion of a hairy vetch cover crop as green manure in watermelon production resulted in suppression of Fusarium wilt caused by Fusarium oxysporum f. sp. niveum in Maryland $(10,25,29)$ and South Carolina (10). In a recent Maryland study, gummy stem blight was reduced, fungicide use was decreased, and watermelon yield was increased following a hairy vetch cover crop when disease pressure was not high (28). Research also has demonstrated a reduction of disease and an increase of yield on other vegetable crops following no-till cover crops $(7,14,17,23)$. Production of tomato in a hairy vetch mulch system has been shown to reduce early blight caused by Alternaria solani and Septoria leaf spot caused by Septoria lycopersici in Maryland (14) and Ohio (23). Producing pumpkin on a no-till hairy vetch cover crop reduced Plectosporium blight caused by Plectosporium tabacinum and fruit black rot caused by $D$. bryoniae, and increased fruit yield compared with a conventionally tilled, bare-ground treatment (7). A notill wheat cover crop greatly reduced the development of Phytophthora blight caused by Phytophthora capsici in pepper (17).

Although disease reductions have been shown on watermelon grown where a hairy vetch cover crop was used as green manure $(10,25,28,29)$, there has been no research conducted to understand the effects of a no-till hairy vetch cover crop on the development of anthracnose and gummy stem blight and on the growth and fruit yield of watermelon. Additional benefits of using a no-till hairy vetch cover crop may accrue in the replacement of polyethylene film and the reduced use of fertilizers (22). The objectives of this study were to compare disease severity, plant growth, and fruit yield of watermelon grown on a no-till hairy vetch cover crop with 
two conventional bedding systems (black polyethylene mulch and bare ground) and with fungicide applications. The overarching goal was to determine the potential of using a no-till hairy vetch cover crop as an alternative management option for anthracnose and gummy stem blight on watermelon in the mid-Atlantic region. Preliminary results of this study have been reported previously (30).

\section{Materials and Methods}

Plot establishment. The experiments were conducted in 2005, 2006, and 2007 on a Norfolk "A" loamy sand soil at the University of Maryland's Lower Eastern Shore Research and Education Center, Salisbury, MD. Each year, plots consisted of a single raised bed $13.7 \mathrm{~m}$ long, $18 \mathrm{~cm}$ high, and $0.8 \mathrm{~m}$ wide on 1.8 - $\mathrm{m}$ centers. The experiments were conducted as a split-plot design with four replications. The main-plot treatments were bare ground, black polyethylene mulch, or a cover crop of hairy vetch (cultivar unspecified; Farmers and Planters Co., Salisbury, MD) that was planted in late fall, grown on raised beds, killed in the following spring, and left on the surface as an organic mulch. The subplot treatments were a nonfungicide control or a weekly scheduled fungicide spray program. Hairy vetch was inoculated with a commercial formulation of Rhizobium spp. (N-DURE; INTX Microbials, LLC, Kentland, IN) prior to planting, and seeded on permanently raised beds at $45 \mathrm{~kg} / \mathrm{ha}$ on 7 October $2004,45 \mathrm{~kg} / \mathrm{ha}$ on 17 October 2005, or $34 \mathrm{~kg} / \mathrm{ha}$ on 10 October 2006. Paraquat (Gramoxone Extra $2.5 \mathrm{SC}, 0.5 \mathrm{~kg}$ a.i./ha) was applied to all ground cover and fallow plots to kill hairy vetch and weeds on 17 May 2005, 16 May 2006, or 9 May 2007. Prior to herbicide application, aboveground hairy vetch biomass was collected in two 1-by-1-m areas arbitrarily selected on the edge of each plot and was air dried in a greenhouse for estimation of plant biomass and nutrient $(\mathrm{N})$ content. Plots without hairy vetch were left fallow over winter. Tillage was performed only in fallow areas assigned for bare ground and polyethylene-covered plots by moldboard-plowing to a depth of $20 \mathrm{~cm}$. Raised beds were shaped in all plots except for those with hairy vetch. Black polyethylene film $(1.25 \mathrm{mil})$ was installed over the designed beds. The triploid (seedless) watermelon 'Millionaire' was seeded in a greenhouse on 18 May 2005, 28 April 2006, or 1 May 2007 and was transplanted $0.9 \mathrm{~m}$ apart within rows on 17 June 2005, 31 May 2006, or 30 May 2007. The diploid (seeded) watermelon 'Royal Majesty' was transplanted to every third bed, which was covered with black polyethylene film, and served as the pollenizer.

A fertilizer program was applied for bare-ground and polyethylene plots (winter fallow plots) based on soil tests and applied for hairy vetch plots based on the estimated contribution of hairy vetch biomass to $\mathrm{N}$ content (22). Bare-ground and polyethylene-covered plots received $16-3-18(\mathrm{~N}-\mathrm{P}-\mathrm{K})$ at $741 \mathrm{~kg} / \mathrm{ha}$ in $2005,16-3-19$ plus $\mathrm{S}(5 \%)$ and $\mathrm{B}(0.2 \%)$ at $1,029 \mathrm{~kg} / \mathrm{ha}$ in 2006 , and $16-3-19$ plus $\mathrm{S}$ $(5 \%)$ and $\mathrm{B}(0.2 \%)$ at $741 \mathrm{~kg} / \mathrm{ha}$ in 2007 by soil incorporation before bedding. Hairy vetch plots received $0-3-18$ at $741 \mathrm{~kg} / \mathrm{ha}$ in $2005,0-3-19$ plus $\mathrm{S}(5 \%)$ and $\mathrm{B}(0.2 \%)$ at $1,029 \mathrm{~kg} / \mathrm{ha}$ in 2006 , and $0-3-19$ plus $\mathrm{S}(5 \%)$ and $\mathrm{B}(0.2 \%)$ at $741 \mathrm{~kg} / \mathrm{ha}$ in 2007 by broadcasting over beds before transplanting. A $250-\mathrm{ml}$ solution of Peter's Plant Starter fertilizer (20-20-20 at $1.13 \mathrm{~kg}$ per 568 liters of water) was applied to each plant at transplanting.

Weeds were controlled by application of ethalfluralin (Curbit 3E, $0.84 \mathrm{~kg}$ a.i./ha) and terbacil (Sinbar WP, $0.17 \mathrm{~kg}$ a.i./ha) over all plots prior to transplanting. Manual weeding took place when necessary. Transplants were drenched with the insecticide imidacloprid (Admire Pro at $0.028 \mathrm{~g}$ a.i. per seedling) before transplanting to control Colorado potato beetle (Leptinotarsa decemlineata ). All plots were overhead irrigated as needed.

Fungicide spray program. Fungicide spray programs were either no fungicides applied or weekly fungicide applications. The fungicide applications began when the vines of watermelon plants were approximately $0.5 \mathrm{~m}$ long, which took place on 14 July 2005 , 5 July 2006, and 26 June 2007. Sprays were terminated 1 week before harvest. Chlorothalonil (Bravo Ultrex 82.5WG, $2.5 \mathrm{~kg}$ a.i./ha) in tank mix with azoxystrobin (Quadris $2.08 \mathrm{SC}, 0.28 \mathrm{~kg}$ a.i./ha) in 2005 and 2006 or pyraclostrobin plus boscalid (Pristine $38 \mathrm{WG}, 0.39 \mathrm{~kg}$ a.i./ha) in 2007 were applied weekly. These fungicides and application schedules were commonly used for commercial watermelon production in the mid-Atlantic region. There were five, six, and five applications for 2005, 2006, and 2007, respectively. Fungicides were applied with a tractor-mounted sprayer. The boom of the sprayer was equipped with six D4-45 hollowcone nozzles that delivered 421 liters/ha at $296 \mathrm{kPa}$. Two of the nozzles spaced $45.7 \mathrm{~cm}$ apart were positioned above the canopy; two drop nozzles on each side of the row that was $35.6 \mathrm{~cm}$ apart were set to spray into the canopy.

Disease rating. The trials were established in a field with natural inoculum of both pathogens of anthracnose and gummy stem blight, resulting from repeated planting of watermelon and other cucurbitaceous crops for many years. Severity of anthracnose and gummy stem blight was measured as the percentage of symptomatic foliage, which was visually assessed based on the whole plot using a Horsfall-Barratt scale (0 to 11). Both diseases were rated weekly after transplanting until 1 week before harvest and were distinguished based on their characteristic symptoms $(19,20)$. Horsfall-Barratt ratings were converted to percent leaf area diseased within the whole plot, with the midpoint of the percent ranges represented by each rating. The percentage of all fruit with one or more lesions of anthracnose or gummy stem blight also was evaluated for each plot at harvest. Based on observations before and during the study, the lesions on fruit were predominately caused by anthracnose in the mid-Atlantic environmental conditions.

Plant growth and fruit yield. To assess plant growth, three plants were randomly selected from each plot and the length of their primary vines was measured at harvest. Marketable fruit were harvested and weighed individually and sugar content in three fruit randomly selected from each plot was measured with a hand-held refractometer on 31 August 2005, 16 August 2006, or 9 August 2007. Marketable fruit were defined as those weighing $4.5 \mathrm{~kg}$ or above each.

Data analysis. The experiments were analyzed as a split-plot design using PROC MIXED. The area under the disease progress curve (AUDPC) was calculated from severity data with the standard iterative process (18). Data for AUDPC, vine length, diseased fruit, and marketable fruit were subjected to analysis of variance. When a significant interaction between ground cover and fungicide was present, means were separated by $t$ tests of least squares means at $P \leq 0.05$. When no significant interaction was present, means of ground cover treatments were calculated across the two fungicide treatments, fungicide means were calculated across all ground cover treatments, and contrasts were used to compare ground cover treatments with each other, to compare the hairy vetch treatment with the fungicide treatment, and to compare the unsprayed fungicide control with the fungicide treatment. All data analyses were performed with the Statistical Analysis System (version 8.2; SAS Institute, Cary, NC).

\section{Results}

Hairy vetch growth. Each year, hairy vetch survived over winter and resumed its growth in early spring. Hairy vetch cover crops formed consistent and firm organic mulch after being killed. The aboveground biomass of hairy vetch averaged 6.5, 7.7, and 6.4 tons (dry weight)/ha in 2005, 2006, and 2007, respectively.

Disease. In the 2005 trial, the magnitude of the impacts of the ground cover treatment on AUDPC of anthracnose was independent of fungicides applied (Table 1). Hairy vetch plots had a significant $(P<0.0001)$ delay in anthracnose development and a significantly $(P<0.0001)$ lower level of final anthracnose severity compared with black polyethylene or bare-ground plots (Fig. 1A). Weekly fungicide applications significantly $(P<0.0001)$ reduced final anthracnose severity compared with the no-fungicide control (Fig. 1B). The magnitude of the effects of the cover crop mulch on anthracnose was similar to the magnitude of the reduction in dis- 
ease due to fungicides (Table 2). No significant difference in AUDPC value of anthracnose between black polyethylene and bare ground was observed. The magnitude of the ground cover treatment differences in gummy stem blight AUDPC was dependent on fungicide application (Table 1). Where fungicides were applied, the AUDPC of gummy stem blight was low and, although the AUDPC in hairy vetch plots ranked below the AUDPC of polyethylene plots, they were not significantly different. However, in nonsprayed plots where the gummy stem blight AUDPC was high, the AUDPC value of gummy stem blight was significantly lower $(P \leq 0.05)$ in plots with hairy vetch compared with bare ground or black polyethylene, with a 65 to $75 \%$ reduction in AUDPC (Table 2). These reductions in AUDPC of gummy stem blight were similar to those obtained with fungicides applied to bare ground or black polyethylene plots. When a hairy vetch cover crop mulch was used, there was no significant effect of fungicide applications on either anthracnose or gummy stem blight (Table 2).

In 2005 , there was no significant interaction between ground cover and fungicide for diseased watermelon fruit (Table 1). The percentage of diseased fruit was significantly lower $(P=0.0001)$ in plots with hairy vetch than with black polyethylene or bare ground, with an 88 to $91 \%$ reduction between them (Table 3). The magnitude of suppression of diseased fruit by hairy vetch was similar to the magnitude of the suppression by fungicides. Watermelon grown on either bare ground or black polyethylene had high and comparable levels of diseased fruit.

In general, the results of the trials conducted in 2006 and 2007 were similar to the results of the trial in 2005. There was a significant $(P=0.0001)$ ground cover and fungicide interaction for AUDPCs of anthracnose and gummy stem blight in 2006 and 2007 (Table 1). In both years, where no fungicide was applied, hairy vetch mulch significantly $(P=0.05)$ suppressed anthracnose and gummy stem blight on the foliage compared with bare ground and black polyethylene (Table 2). Likewise, fewer diseased fruit of watermelon developed on hairy vetch ground cover compared with bare ground or black polyethylene (Table 3). The reductions in disease by hairy vetch were comparable with those achieved with fungicide application, with a 66 to $89 \%$ reduction in AUDPC and a 91 to $96 \%$ reduction in diseased fruit. The AUDPC values for anthracnose and gummy stem blight were comparably high with both bare ground and black polyethylene mulch treatments in 2006 (Table 2). However, these values were significantly higher $(P=0.05)$ in plots with black polyethylene than with bare ground in 2007 . The application of fungicides to hairy vetch-covered plots significantly reduced $(P=0.05)$ anthracnose in 2007 and reduced gummy stem blight in 2006 and 2007 over hairy vetch-covered plots without fungicides. Both bare ground and black polyethylene mulch treatments produced high and comparable levels of diseased fruit (Table 3).
When regression analysis was completed on all 3-year combined data for AUDPC of anthracnose and diseased watermelon fruit, the percentage of diseased fruit ( $Y$, percent diseased fruit) was significantly increased with the increase of anthracnose severity $(X$, AUDPC) on the foliage, with a regression equation of $Y=0.027 X$ $+0.8343\left(R_{\text {adj. }}^{2}=0.57, P<0.0003\right)$.

Vine growth. There were no significant ground cover-fungicide interactions for watermelon vine length each year (Table 1). Water-
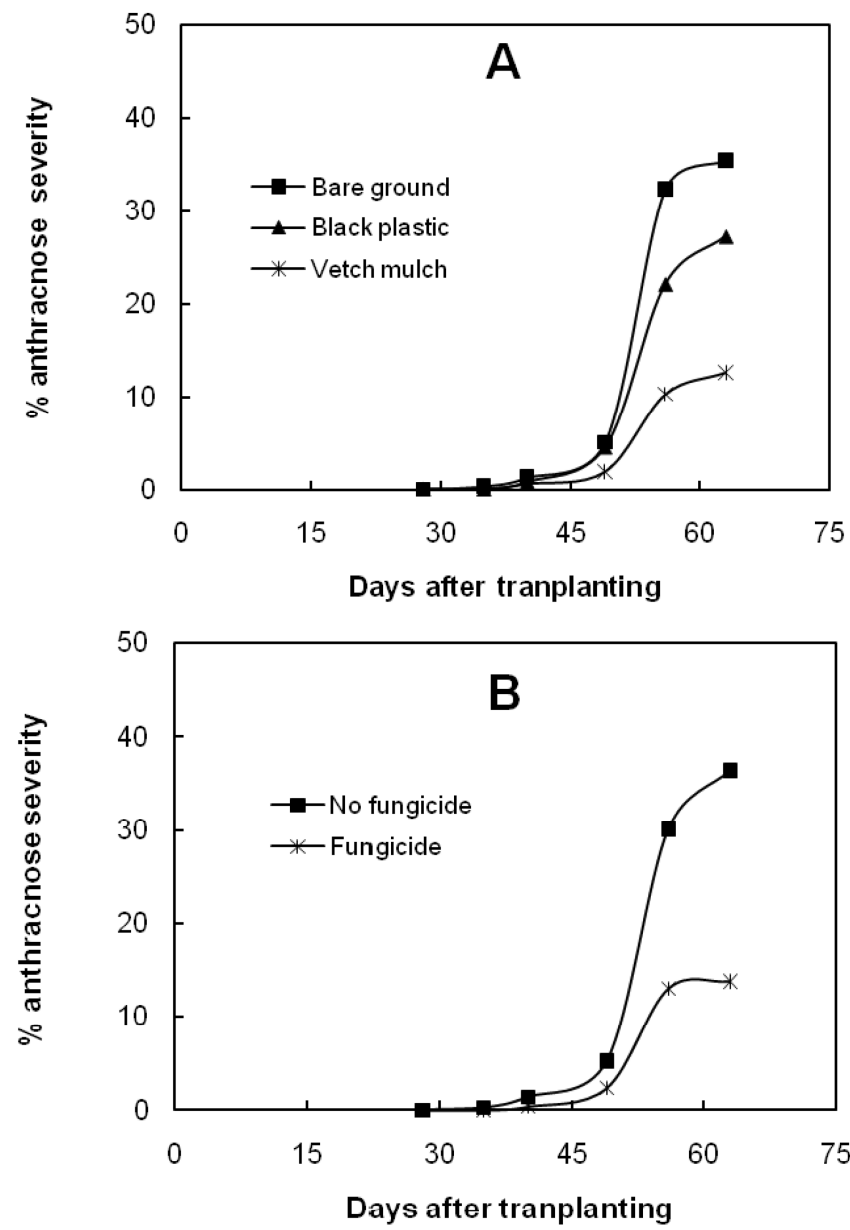

Fig. 1. Anthracnose progress curves in 2005 for $\mathbf{A}$, ground covers averaged over both fungicide treatments and $\mathbf{B}$, fungicide treatments averaged over all ground covers. Ground cover-fungicide interaction was not significant $(P=0.1366)$. Data points are means of four replicated plots.

Table 1. Variance analysis for the effects of ground cover and fungicide treatment on the area under the disease progress curve (AUDPC) for anthracnose and gummy stem blight, vine length, diseased fruit, and marketable fruit yield of watermelon in 2005, 2006, and 2007w

\begin{tabular}{|c|c|c|c|c|c|c|}
\hline \multirow[b]{2}{*}{ Variables $^{x}$} & \multicolumn{2}{|c|}{ AUDPC } & \multirow[b]{2}{*}{ Vine length ${ }^{y}$} & \multirow[b]{2}{*}{ Diseased fruit ${ }^{\mathrm{z}}$} & \multicolumn{2}{|c|}{ Marketable fruit } \\
\hline & Anthracnose & Gummy stem blight & & & Yield & Sucrose \\
\hline \multicolumn{7}{|l|}{2005} \\
\hline Ground cover & 0.0008 & 0.0061 & 0.0001 & 0.0001 & 0.0062 & 0.0077 \\
\hline Fungicide & 0.0001 & 0.0001 & 0.0001 & 0.0002 & 0.0007 & 0.9044 \\
\hline Ground cover $\times$ fungicide & 0.1366 & 0.0021 & 0.2855 & 0.2632 & 0.5589 & 0.5189 \\
\hline \multicolumn{7}{|l|}{2006} \\
\hline Ground cover & 0.0008 & 0.0001 & 0.0336 & 0.0168 & 0.0005 & 0.0099 \\
\hline Fungicide & 0.0001 & 0.0001 & 0.5494 & 0.0019 & 0.0295 & 0.7435 \\
\hline Ground cover $\times$ fungicide & 0.0001 & 0.0001 & 0.0531 & 0.2708 & 0.0738 & 0.5083 \\
\hline \multicolumn{7}{|l|}{2007} \\
\hline Ground cover & 0.0001 & 0.0001 & 0.0027 & 0.0005 & 0.0007 & 0.2162 \\
\hline Fungicide & 0.0001 & 0.0001 & 0.0117 & 0.0001 & 0.0209 & 0.6040 \\
\hline Ground cover $\times$ fungicide & 0.0001 & 0.0001 & 0.0970 & 0.0022 & 0.2602 & 0.1160 \\
\hline
\end{tabular}

${ }^{\mathrm{w}} P$ values smaller than 0.05 indicate statistical significance at the $5 \%$ level.

${ }^{\mathrm{x}}$ Ground cover consisted of bare (uncovered) ground, black polyethylene, and killed hairy vetch mulch.

${ }^{y}$ Length of main vines of three plants per plot was determined at fruit harvest.

${ }^{\mathrm{z}}$ Percentage of fruit, based on all sizes of fruit, with one or more lesions of anthracnose or gummy stem blight. 
melon plants grown on hairy vetch mulch had a significantly longer $(P \leq 0.0409)$ length of main vines than plants grown on black polyethylene in 2005 and 2007, with a similar vine length in 2006 (Table 4). The magnitude of the effects of hairy vetch mulch on vine length was similar to (2006 and 2007) or greater than (2005) the magnitude of the increase in vine length due to fungicide applications. Vine length was significantly greater $(P \leq$ $0.0328)$ in plots with polyethylene compared with bare ground in 2005 and 2006.

Fruit yield. The ground cover-fungicide interactions were not significant in any year for yield and sugar content of marketable fruit (Table 1). Marketable yield was significantly greater $(P \leq$ 0.007 ) in plots with hairy vetch compared with bare ground in 2006 and 2007 (Table 3). Marketable yield in plots covered with hairy vetch was significantly higher $(P=0.0278)$ in 2007 but lower in 2005 and 2006 when compared with plots covered with polyethylene. The magnitude of the effects of the hairy vetch mulch on marketable yield was similar to the magnitude of the increase in yield due to fungicide applications in all 3 years. The application of fungicides to hairy vetch-covered plots did not increase yield significantly over hairy vetch-covered plots without fungicides. Each year, polyethylene mulch had a significantly higher yield $(P$ $\leq 0.0086$ ) than bare ground. In 2005 and 2006, sugar content in marketable fruit of watermelon grown on hairy vetch $(11.85 \%$, averaged over 2 years) was significantly $(P<0.05)$ greater than on bare ground $(10.95 \%)$ and was similar to sugar content in watermelon grown on polyethylene (11.9\%) (Table 1). Fungicide application did not significantly improve sugar content in marketable fruit in any year (data not shown).

\section{Discussion}

This study clearly demonstrates that the change of bedding system from black polyethylene or bare ground to hairy vetch mulch can have a significant impact on epidemics of anthracnose and gummy stem blight on watermelon. Hairy vetch mulch consistently and substantially reduced anthracnose and gummy stem blight in all 3 years evaluated. These reductions were associated with a delay in disease development and a reduction in AUDPC values and percentage of diseased watermelon fruit.

The suppression of anthracnose and gummy stem blight in the hairy vetch production system may be attributed to reduced rainsplash dispersal of inoculum. Effective dispersal of initial inoculum (conidia) from the soil surface to leaves and subsequent spread of secondary inoculum to new plant tissues are an essential component in the development of epidemics of anthracnose and gummy stem blight $(9,19,20)$. The killed hairy vetch cover crop in this

Table 4. Effects of ground cover and fungicide treatments on the vine length of watermelon in 2005, 2006, and 2007

\begin{tabular}{llll}
\hline & \multicolumn{3}{c}{ Vine length (cm) } \\
\cline { 2 - 4 } Treatment & $\mathbf{2 0 0 5}$ & $\mathbf{2 0 0 6}$ & $\mathbf{2 0 0 7}$ \\
\hline Bare ground & 312 & 277 & 265 \\
Black polyethylene & 345 & 296 & 290 \\
Vetch mulch & 404 & 300 & 318 \\
No fungicide & 330 & 289 & 276 \\
Fungicide & 377 & 293 & 305 \\
Contrast & & & \\
Vetch vs. bare ground $^{z}$ & 0.0001 & 0.0152 & 0.0007 \\
Vetch vs. black polyethylene & 0.0001 & 0.6478 & 0.0409 \\
Vetch vs. fungicide & 0.0002 & 0.3686 & 0.3931 \\
Black polyethylene vs. bare ground & 0.0005 & 0.0382 & 0.0639 \\
Fungicide vs. no fungicide & 0.0001 & 0.5494 & 0.0117 \\
\hline
\end{tabular}

${ }^{y}$ Length of main vines of three plants per plot was determined at fruit harvest. Means are the average of four replicated plots. Ground cover treatments are averaged across both fungicide and no fungicide; fungicide treatments are averaged across three ground covers.

${ }^{z}$ Probability of a greater $F$ value for the contrast between paired treatments.

Table 2. Effects of ground cover and fungicide treatments on the area under the disease progress curve (AUDPC) for anthracnose and gummy stem blight of watermelon in 2005,2006 , and 2007

\begin{tabular}{|c|c|c|c|c|c|c|c|}
\hline \multirow{2}{*}{\multicolumn{2}{|c|}{ Treatment }} & \multicolumn{6}{|c|}{$\mathbf{A U D P C}^{\mathbf{z}}$} \\
\hline & & \multicolumn{3}{|c|}{ Anthracnose } & \multicolumn{3}{|c|}{ Gummy stem blight } \\
\hline Ground cover & Fungicide & 2005 & 2006 & 2007 & 2005 & 2006 & 2007 \\
\hline Bare ground & None & $554 \mathrm{a}$ & $441 \mathrm{a}$ & $799 \mathrm{~b}$ & $643 a$ & $822 \mathrm{a}$ & $694 \mathrm{~b}$ \\
\hline Black polyethylene & None & $425 \mathrm{a}$ & $424 \mathrm{a}$ & 964 a & $478 \mathrm{a}$ & $795 \mathrm{a}$ & $1,029 \mathrm{a}$ \\
\hline Vetch mulch & None & $193 \mathrm{bc}$ & $49 \mathrm{~b}$ & $256 \mathrm{c}$ & $162 \mathrm{~b}$ & $224 \mathrm{~b}$ & $179 \mathrm{~d}$ \\
\hline Bare ground & Fungicide & $249 \mathrm{~b}$ & $67 \mathrm{~b}$ & $202 \mathrm{~cd}$ & $290 \mathrm{~b}$ & $190 \mathrm{bc}$ & $170 \mathrm{de}$ \\
\hline Black polyethylene & Fungicide & $157 \mathrm{bc}$ & $46 \mathrm{~b}$ & $249 \mathrm{c}$ & $223 b$ & $183 \mathrm{bc}$ & $286 \mathrm{c}$ \\
\hline Vetch mulch & Fungicide & $77 \mathrm{c}$ & $43 \mathrm{~b}$ & $143 \mathrm{~d}$ & $115 \mathrm{~b}$ & $126 \mathrm{c}$ & $131 \mathrm{e}$ \\
\hline
\end{tabular}

${ }^{\mathrm{z}}$ Means within the same column followed by the same letter do not differ at $P \leq 0.05$ based on $t$ tests of least-squares means. Means are the average of four replicated plots.

Table 3. Effects of ground cover and fungicide treatments on diseased fruit and marketable fruit yield of watermelon in 2005 , 2006, and 2007

\begin{tabular}{|c|c|c|c|c|c|c|}
\hline \multirow[b]{2}{*}{ Treatment } & \multicolumn{3}{|c|}{ Diseased fruit $(\%)^{\mathrm{x}, \mathrm{y}}$} & \multicolumn{3}{|c|}{ Marketable fruit yield $(\mathrm{t} / \mathrm{ha})^{\mathrm{x}}$} \\
\hline & 2005 & 2006 & 2007 & 2005 & 2006 & 2007 \\
\hline Bare ground & 13.7 & 12.6 & 8.4 & 35.4 & 36.3 & 43.5 \\
\hline Black polyethylene & 17.9 & 12.5 & 11.7 & 53.1 & 65.8 & 54.5 \\
\hline Vetch mulch & 1.6 & 1.1 & 0.5 & 38.6 & 52.4 & 63.3 \\
\hline No fungicide & 17.4 & 14.6 & 12.4 & 39.3 & 48.5 & 51.0 \\
\hline Fungicide & 4.7 & 2.6 & 1.3 & 45.4 & 54.4 & 56.6 \\
\hline \multicolumn{7}{|l|}{ Contrast $\mathrm{z}^{\mathrm{z}}$} \\
\hline Vetch vs. bare ground & 0.0001 & 0.0126 & 0.0011 & 0.4723 & 0.0070 & 0.0002 \\
\hline Vetch vs. black polyethylene & 0.0001 & 0.0100 & 0.0002 & 0.0088 & 0.0183 & 0.0278 \\
\hline Vetch vs. fungicide & 0.0566 & 0.2918 & 0.2712 & 0.0569 & 0.9400 & 0.7461 \\
\hline Black polyethylene vs. bare ground & 0.2932 & 0.8561 & 0.0559 & 0.0028 & 0.0001 & 0.0086 \\
\hline Fungicide vs. no fungicide & 0.0002 & 0.0019 & 0.0001 & 0.0007 & 0.0295 & 0.0209 \\
\hline
\end{tabular}

${ }^{\mathrm{x}}$ Means are the average of four replicated plots. Ground cover treatments are averaged across both fungicide and no fungicide; fungicide treatments are averaged across three ground covers.

y Percentage of fruit, based on all sizes of fruit, with one or more lesions of anthracnose or gummy stem blight.

${ }^{\mathrm{z}}$ Probability of a greater $F$ value for the contrast between paired treatments. 
study produced a firm organic mulch that covered the soil surface through the middle of the watermelon-growing season. Compared with the bare-ground treatment, hairy vetch mulch may provide an effective physical barrier to the dispersal of inoculum, helping reduce initial inoculum from soil reaching watermelon leaves. Compared with polyethylene mulch, hairy vetch mulch might be more effective in reducing runoff of surface water and the splash dispersal of inoculum for secondary infection, resulting in less development of anthracnose and gummy stem blight on the foliage and fruit. Movement in surface water is the primary method of long-range dispersal of inoculum of anthracnose pathogens in agricultural fields $(9,19,20)$. In studies evaluating the effects of ground cover on the spread of anthracnose on strawberry caused by $C$. acutatum, it was observed that polyethylene mulch had the greatest dispersal of spores, surface-applied straw had the least dispersal, and bare ground had the intermediate dispersal $(13,24)$. A sudan grass cover crop (Sorghum bicolor) reduced the splash dispersal of conidia of $C$. acutatum on strawberry (16). Reduced soil splash dispersal has been reported to be one of the primary mechanisms associated with the suppression of early blight and Septoria leaf spot in tomato by hairy vetch mulch (15) and with the suppression of Phytophthora blight in bell pepper by a no-till wheat cover crop (17).

However, other mechanisms, including induced resistance, improved plant nutrition, and the presence of a more beneficial soil microbial community, also may be associated with disease suppression in the hairy vetch mulch treatment in the present study. Induced resistance to Fusarium wilt in watermelon grown in hairy vetch-amended soil was observed in a preliminary study (27). A study on tomato grown on hairy vetch mulch found that induced resistance through the upregulation of disease defense genes that code for chitinase and osmotin was observed compared with tomato grown on black polyethylene mulch (12). Also on tomato, there was an increase in total $\mathrm{N}$ content $(2,3)$ and a reduction in $\mathrm{P}$ (15) when grown on a no-till hairy vetch cover crop compared with tomato grown on polyethylene mulch. The use of a no-till hairy vetch cover crop also resulted in favorable soil fungal and bacterial communities for the growth of tomato (5). Similarly, hairy vetch green manure increased the populations of soil bacteria that closely related to the reduction of Fusarium wilt in watermelon (26).

Increased vine lengths were observed with hairy vetch mulch compared with bare ground and black polyethylene in this study. Marketable fruit yield and sugar content in fruit also were improved with hairy vetch mulch compared with bare ground. These benefits of improved plant growth and fruit yield and quality could be partially attributed to improved soil nutrition, which occurred with the hairy vetch cover crop. Although the hairy vetch plots did not receive additional fertilizer $\mathrm{N}$, hairy vetch residue had the potential of providing total $\mathrm{N}$ at 238,321 , and $238 \mathrm{~kg} / \mathrm{ha}$ in 2005 , 2006, and 2007, respectively. All of this organic N probably provided more available and longer-lasting $\mathrm{N}$ for plant uptake over a season compared with the fertilizer $\mathrm{N}$ amounts applied at planting to the bare ground or polyethylene plots, which were 119,165 , and $119 \mathrm{~kg} / \mathrm{ha}$ in 2005,2006 , and 2007, respectively. A 7- to 10-day delay in leaf senescence observed in the hairy vetch plots in the current study supports this explanation (X. G. Zhou, unpublished data). Similar results have been reported on tomato grown in hairy vetch mulch compared with those grown in black polyethylene and bare ground (1-3). In addition, hairy vetch also increased other minor nutrients required for watermelon growth and improved soil properties, including increased water retention, water infiltration rate, and saturated hydraulic conductivity (22).

The hairy vetch mulch treatment provided similar reductions of anthracnose and gummy stem blight on the foliage and fruit and a similar increase of marketable fruit yield when compared with fungicide spray program with a total of five or six applications per season in this study. These results indicate that, under mid-Atlantic conditions, the hairy vetch production system was very effective in reducing anthracnose and gummy stem blight and that the use of this system has the potential to eliminate or reduce the need for application of fungicides. This confirms the results of our previous study in which severity of gummy stem blight was reduced and fewer applications of fungicides were made when watermelon plants were grown in hairy vetch-incorporated soil (28). Other studies also have documented a reduction in need for fungicide applications on tomato (14) and pumpkin (7) when using a no-till hairy vetch cover crop compared with bare-ground production.

Black polyethylene mulch is the most common bedding practice for watermelon production in the mid-Atlantic and other regions of the United States, although the bare-ground production system is also used in some watermelon production areas. This conventional polyethylene watermelon production relies heavily on the utilization of chemical fungicides, synthetic fertilizer, black polyethylene, and tillage to maximize the yield and quality of watermelon crops. Our study indicates that a no-till hairy vetch cover crop can be used as an alternative system for watermelon production under mid-Atlantic conditions. One of the most attractive features of this system is its ability to reduce anthracnose and gummy stem blight and potentially reduce fungicide inputs. Additional benefits of this system are its capability to supply most or all of the $\mathrm{N}$ requirement for the watermelon plant, the replacement of polyethylene film, and significant reduction of tillage. Therefore, the hairy vetch production system described here may offer environmental and economic advantages to watermelon growers. A similar hairy vetch production system has been previously reported to provide disease reductions and yield increases in tomato in Maryland $(1,14)$ and Ohio (23) and in pumpkin in Maryland (7). However, hairy vetch mulch benefits may vary region to region due to change in climate, soil type, and cropping systems. Insufficient biomass produced by hairy vetch is one of the constraints to adoption of this production practice for disease control. Delay in watermelon maturity due to reduced early spring soil temperatures associated with no-till hairy vetch also may limit its adoption (1). In addition, a modification of the current hairy vetch production system may provide a viable option to mitigate damage caused by anthracnose and gummy stem blight in organic production or during the 3-year organic transition period.

\section{Literature Cited}

1. Abdul-Baki, A. A., Stommel, J. R., Watada, A. E., Teasdale, J. R., and Morse, R. D. 1996. Hairy vetch mulch favorably impacts yield of processing tomatoes. HortScience 31:338-340.

2. Abdul-Baki, A. A., Teasdale, J. R., and Korcak, R. F. 1997. Nitrogen requirements of fresh-market tomatoes on hairy vetch and black polyethylene mulch. HortScience 32:217-221.

3. Abdul-Baki, A. A., Teasdale, J. R., and Korcak, R. F., Chitwood, D. J., and Huettel, R. N. 1996. Fresh-market tomato production in a low input alternative system using cover-crop mulch. HortScience 31:65-69.

4. Allred, A. J., and Lucier, G. 1990. The U. S. Watermelon Industry. Staff Report No. AGES 9015. U. S. Dep. Agric. Washington, DC.

5. Carrera, L. M., Buyer, J. S., Vinyard, B., Abdul-Baki, A. A., Sikora, L. J., and Teasdale, J. R. 2007. Effects of cover crops, compost, and manure amendments on soil microbial community structure in tomato production systems. Appl. Soil Ecol. 37:247-255.

6. Everts, K. L. 1999. First report of benomyl resistance in Didymella bryoniae in Delaware and Maryland. Plant Dis. 83:304.

7. Everts, K. L. 2002. Reduced fungicide applications and host resistance for managing three diseases in pumpkin grown on a no-till cover crop. Plant Dis. 86:1134-1141.

8. Keinath, A. P. 2001. Effect of fungicide applications scheduled to control gummy stem blight on yield and quality of watermelon fruit. Plant Dis. 85:53-58.

9. Keinath, A. P., and Duthie, J. A. 1998. Yield and quality reductions in watermelon due to anthracnose, gummy stem blight, and black rot. Recent Res. Dev. Plant Pathol. 2:77-90.

10. Keinath, A. P., Hassell, R L., Everts, K. L., and Zhou, X. G. 2010. Cover crops of hybrid common vetch reduce Fusarium wilt of seedless watermelon in the Eastern United States. Online publication. Plant Health Progress doi:10.1094/PHP-2010-0914-01-RS

11. Keinath, A. P., and Zitter, T. A. 1998. Resistance to benomyl and thiophanate-methyl in Didymella bryoniae from South Carolina and New York. Plant Dis. 82:479-484.

12. Kumar, V., Mills, D. J., Anderson, J. D., and Matoo, A. K. 2004. An alternative agriculture system is defined by a distinct expression profile of select gene transcripts and proteins. Proc. Natl. Acad. Sci. USA 101:10535-10540.

13. Madden, L. V., Wilson, L. L., and Ellis, M. A. 1993. Field spread of 
anthracnose fruit rot of strawberry in relation to ground cover and ambient weather conditions. Plant Dis. 77:861-866.

14. Mills, D. L., Coffman, C. B., Teasdale, J. R., Everts, K. L., Abdul-Baki, A. A., Lydon, J., and Anderson, J. D. 2002. Foliar disease in fresh-market tomato grown in differing bed strategies and fungicide spray programs. Plant Dis. 86:955-959.

15. Mills, D. L., Coffman, C. B., Teasdale, J. R., Everts, K. L., and Anderson, J. D. 2002. Factors associated with foliar disease of staked fresh market tomatoes grown under differing bed strategies. Plant Dis. 86:356-361.

16. Ntahimpera, N., Ellis, M. A., Wilson, L. L., and Madden, L. V.1998. Effects of a cover crop on splash dispersal of Colletotrichum acutatum conidia. Phytopathology 88:536-543.

17. Ristaino, J. B., Parra, G., and Campbell, C. L. 1997. Suppression of Phytophthora blight in bell pepper by a no-till wheat cover crop. Phytopathology 87:242-249.

18. Shaner G., and Finney, R. E. 1977. The effect of nitrogen fertilization on the expression of slow-mildewing resistance in Knox wheat. Phytopathology 67:1051-1056

19. Sitterly, W. R., and Keinath, A. P., 1996. Anthracnose. Pages 24-25 in: Compendium of Cucurbit Diseases. T. A. Zitter, D. L. Hopkins, and C. E. Thomas, eds. American Phytopathological Society, St. Paul, MN.

20. Sitterly, W. R., and Keinath, A. P., 1996. Gummy stem blight. Pages 27-28 in: Compendium of Cucurbit Diseases. T. A. Zitter, D. L. Hopkins, and C. E. Thomas, eds. American Phytopathological Society, St. Paul, MN.

21. Stevenson, K. L., Langston, D. B., Jr., and Seebold, K. W. 2004. Resistance to azoxystrobin in the gummy stem blight pathogen documented in Georgia. Online publication. Plant Health Progress doi:10.1094/PHP-2004-1207-01RS.
22. Sustainable Agriculture Network. 1998. Hairy vetch. Pages 112-119 in: Managing Cover Crops Profitably. G. Bowman, C. Shirley, and C. Cramer, eds. Washington, DC.

23. Wyenandt, C. A., Rhodes, L. H., Riedel, R. M., and Bennett, M. A. 2008. Cover crop mulch and fungicide program affect development of Septoria leaf spot and marketable yield in processing tomato production. HortScience 43:807-810.

24. Yang, X., Madden, L. V., Wilson, L. L., and Ellis, M. A. 1990. Effects of surface topography and rain intensity on splash dispersal of Colletotrichum acutatum. Phytopathology 80:1115-1120.

25. Zhou, X. G., and Everts, K. L. 2006. Suppression of Fusarium wilt of watermelon enhanced by hairy vetch green manure and partial cultivar resistance. Online publication. Plant Health Progress doi:10.1094/PHP2006-0405-01-RS.

26. Zhou, X. G., and Everts, K. L. 2007. Effects of host resistance and inoculum density on the suppression of Fusarium wilt of watermelon induced by hairy vetch. Plant Dis. 91:92-96.

27. Zhou, X. G., and Everts, K. L. 2008. Hairy vetch-induced systemic resistance to Fusarium wilt in watermelon. (Abstr.) Phytopathology 98:S180.

28. Zhou, X. G., and Everts, K. L. 2008. Integrated management of gummy stem blight of watermelon by green manure and Melcast-scheduled fungicides. Online publication. Plant Health Progress doi:10.1094/PHP-2008 1120-01-RS.

29. Zhou, X. G., and Everts, K. L. 2004. Suppression of Fusarium wilt of watermelon by soil amendment with hairy vetch. Plant Dis. 88:1357-1365.

30. Zhou, X. G., and Everts, K. L. 2007. Watermelon grown on a no-till hairy vetch cover crop is a new alternative practice for management of anthracnose and gummy stem blight. (Abstr.) Phytopathology 97:S130. 